\title{
God is Light and Living in the Light: Reading 1 John 1-2 in Light of Discourse Analysis
}

\author{
Chandra Gunawan \\ Theologische Universiteit, Kampen, Belanda \\ Korespondensi: rev.chandragunawan@gmail.com \\ Diajukan: 04-Ags-2017; Direview: 02-Okt-2017; Diterima: 23-Okt-2017; Direvisi: 28-Okt-2017
}

\begin{abstract}
The notion that "God is light" is essential to the understanding of the literary structure of 1 John because it links units of thought in the Epistle. This central idea and its ethical implications, "living in the light" and "living in love," develop throughout the letter. To understand the function of this concept and to grasp its meaning in 1 John, the present study utilizes discourse analysis to read the document in light of its micro and macro structures. Interpreting the "God is light" teaching in the Epistle-based on its literary structure-will shed some light on understanding the main issue addressed in 1 John.
\end{abstract}

KEYWORDS: God; Light; Darkness; 1 John; Antichrist; Discourse Analysis.

ABSTRAK: Pengertian mengenai "Allah adalah terang" sangat penting di dalam mengerti struktur literatur dari 1 Yohanes karena hal ini merantai tiap unit pemikiran di dalam surat ini. Ide yang sentral dan implikasi etikalnya, "hidup di dalam terang" dan "hidup di dalam kasih," dikembangkan di seluruh surat ini. Untuk mengerti fungsi dari konsep ini dan memahami dengan sungguh maknanya di 1 Yohanes, studi ini mendayagunakan analisa wacana untuk membaca dokumen ini dalam terang struktur mikro dan makronya. Dengan menginterpretasi pengajaran "Allah adalah terang" dalam surat ini - berdasarkan struktur literaturnya - akan menerangi pengertian akan hal pokok yang dibicarakan di 1 Yohanes.

KATA KUNCI: Allah; Terang; Kegelapan; 1 Yohanes; Antikristus; 


\section{Analisa Wacana.}

\section{Introduction}

Readers of the New Testament might think that Christology is the most significant concept in 1 John. It is true that the document explicitly mentions an individual (or a group of people) who denies that Jesus is the Christ and who refuses to confess that Jesus has come in the flesh (cf. 1 John 2.22-23; 4.2-3). The Christological issue addressed in this text may indicate that the teaching about Christ is crucial to the recipients. Nevertheless, the logical texture ${ }^{1}$ of 1 John shows that the most important issue in this letter ${ }^{2}$ is probably not Christology.

Compared to Christology, the theme of God in 1 John occurs more prevalently. ${ }^{3}$ The syntactic structure and the logical texture of the letter show that the notion of God enables linking all units of thought in this letter. In 1 John 1.1-5, the author begins his letter with a prologue. ${ }^{4} \mathrm{He}$

1 For a discussion of logical texture in discourse analysis, see M. A. K. Halliday and R. Hasan, Language, Context, and Text: Aspects of Language in a Social Semiotic Perspective (Oxford: Oxford University Press, 1989), chap. 1.

2 The literary form of 1 John is quite different from the other letters in the NT, such as the Letter to the Galatians, but there are still good reasons to identify 1 John as a letter. For

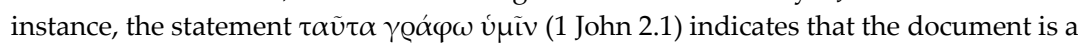
written discourse. Equally important, although ancient writing existed in many forms, including biographies, historiographies, and homilies, the church fathers recognized 1 John as a letter (see, e.g., Eusebius, Hist. eccl. 6.25.6).

3 Cf. R. Alan Culpepper, "Setting the Stage: The Context for the Conversation," in Communities in Disputes: Current Scholarship on the Johannine Epistles (Atlanta: SBL, 2014), 4. Culpepper finds that Johannine scholars who do not follow Brown's approach and who read 1 John as a non-polemical letter usually come to the conclusion that the main theme of 1 John is not Christology but a particular teaching about God.

4 Cf. I. H. Marshall, Epistles of John, NICNT (Grand Rapids: Eerdmans, 1978), 22-26; R. E. Brown, The Epistles of John: A New Translation with Introduction and Commentary, AB 30 (Garden City: Doubleday, 1983), 125; John Painter, 1, 2, and 3 John, SP (Collegeville: Liturgical, 2002), 116-118; Martin M. Culy, I, II, III John: A Handbook on the Greek Text (Waco: Baylor University Press, 2004), 10-11. Most commentators identify 1 John 1.1-4 as the prologue. They use the prologue of the Gospel as a model for the prologue of 1 John and, therefore, exclude 1.5 from the prologue because there is parallelism between 1 John 1.5 and

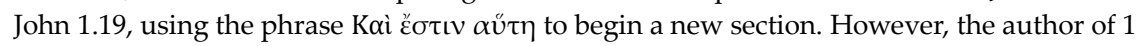
John does not always seem to use this phrase as a marker to begin a new section; he employs the phrase a few times (see, e.g., 2.25 and 3.23) to indicate that he is making a transition, not that he is beginning a new section. In addition, the author repeatedly uses the conjunction $\kappa \alpha i$ in 1.2-5 to indicate that 1.5 is still related to the previous units of thought.

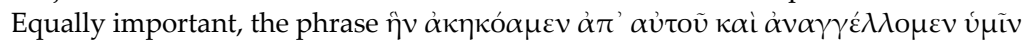




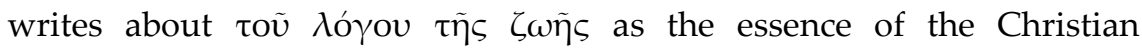
proclamation, the source of eternal life, and the basis for a genuine fellowship. Subsequently, he ends this opening section with the notion that "God is light" (1.5). This idea is pivotal to the literary structure of 1 John since it links the prologue with the first part of the letter's body (1.62.28 ; 2.29-3.1), which underscores the necessity of believers' living in truth and love. In the second part of the body, 3.2-5.12, the author focuses on the themes of "God is love" and "living in love," the latter being concomitant with "living in the light" (see 2.9-11). In the epilogue, 5.13-16, $17-21,5$ while the author states that he wrote the letter so that the addressees will keep believing in Jesus, similar to the prologue, he ends this section with his teaching about God. The hearers are warned that they should avoid $\tau \tilde{\omega} v \varepsilon i \delta \omega \hat{\jmath} \lambda \omega v$ (5.21). Although the author of 1 John does not explain this phrase, the readers must recognize and understand the idea behind the words, and it is possible that $\tau \tilde{\omega} v \varepsilon i \delta \omega \hat{\omega} \lambda \omega v$ refers to traditions concerning idolatry that were, at that time, well-known among Christians. $^{6}$

How does the author of 1 John develop his concept of God, in particular, the notion that "God is light," in his letter? This article will use discourse analysis in order to answer this question. ${ }^{7}$ The method of

semantically connects 1.5 with the previous sentences in the prologue. This phrase is used to help the readers recognize that the message mentioned in 1.5 is a part of Jesus' teaching, which the eyewitnesses heard and which now has become their message. The position of 1.5 in the prologue and the relation between 1.5 and 1.1-4 are important; 1.5 becomes a transition that connects the lines of thought between the opening and the letter's body. Additionally, it functions in the prologue as a final sentence that gives emphasis to the main message, signifying that the audience of the letter should pay close attention to this unit.

5 The epilogue consists of two parts: intersection (5.13-16) and final exhortation (5.17-21).

6 Cf. Terry Griffith, Keep Yourselves from Idols: A New Look at 1 John, JSNTSS 233 [London: Sheffield Academic Press, 2002], 57, 80-81. Griffith finds similar literary styles in 1 John and Jewish literature like Joseph and Aseneth (e.g., the applications of vocative Teкví $\alpha$ and the imperatival phrase $\varphi v \lambda \alpha \dot{\xi} \alpha \tau \varepsilon \ldots \dot{\alpha} \pi \mathrm{o}$, which are found in 1 John 5.21 . He believes that there is a topos regarding the theme of the true God in its relation to the theme of eternal life and the warning to avoid idolatry, and that the author of 1 John must know the topos and is applying it in his letter's closure.

7 For a discussion of discourse analysis in NT interpretation, see J. T. Reed, "Discourse Analysis," in Handbook to Exegesis of the New Testament, ed. S. E. Porter (Leiden: Brill, 1997), 189-217. 
discourse analysis will help to investigate how the "God is light" declaration functions in 1 John based on its logical context: ${ }^{8}$ its micro (sentence, pericope, and paragraph) and macro (units and discourse/text) structures. To understand how 1 John uses the words "light" and "darkness," this study will first investigate the semantic meanings of the words "light" and "darkness" in 1 John. It will utilize the synchronicword-study model to grasp the meanings of the terms "light" and "darkness," focusing its analysis on the vertical and horizontal dimensions of a word meaning. ${ }^{9}$ Secondly, the macro structure of the Epistle will be discussed. Lastly, the development of the "God is light" concept will be observed from the structure of 1 John 1-2.

\section{The Semantic Meaning of "Light" and "Darkness" in the New Testament}

The concepts of "light" and "darkness" are prominent not only in Johannine literature but also in early Jewish literature, especially in the Qumran texts. ${ }^{10}$ While scholars disagree over the influence of the

\footnotetext{
8 Grant R. Osborne, The Hermeneutical Spiral: A Comprehensive Introduction to Biblical Interpretation, 2nd ed. (Downers Grove: IVP, 2006), 39. Osborne defines logical context as an "array of influences on the text," which is uncovered when a passage is read from its broader contexts (e.g., a paragraph, a major section, and a book).

9 For a helpful discussion of the use of modern linguistic study in NT interpretation, see Max Turner, "Modern Linguistic and Word Study in the New Testament," in Hearing the New Testament: Strategies for Interpretation, 2nd ed., ed. J. B. Green (Grand Rapids: Eerdmans, 2010), 189-217.
}

10 Some scholars take note of the linguistic similarities (the usage of the contrastive metaphor "light and darkness," for instance) between 1 John and the Qumran literature, supposing that they share a similar background (cf. Painter, 1, 2, 3 John, 10, 139). However, there is no solid evidence supporting the hypothesis that argues for the influence of this community on 1 John; see Marshall, The Epistles of John, 50-51; David E. Aune, "Dualism in the Fourth Gospel and the Dead Sea Scrolls: A Reassessment of the Problem," in Neotestamentica et Philonica: Studies in Honor of Peder Borgen, ed. David E. Aune et. al., NTS 106 (Leiden: Brill, 2003), 281-303; Richard Bauckham, The Testimony of the Beloved Disciple: Narrative, History, and Theology in the Gospel of John (Grand Rapids: Baker, 2007), 125-136. In the case of $1 \mathrm{John}$, the author underlines that his teaching (that "God is light") stems from

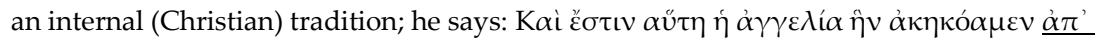

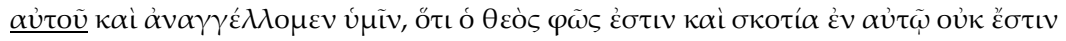

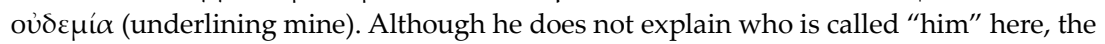
hearers must know this individual well, so much so that they trust in him; it is unlikely that 
Qumran community on the Johannine literature, the phrase has become an idiolect within Johannine traditions. ${ }^{11}$ This does not mean that the Gospel and the Letter use the term univocally; for example, while the first applies the word "light" to Jesus (cf. John 1.9, 8.12), the latter makes use of the metaphor to underline God's essence, which is holy (1 John 1.5).

The NT makes use of the word $\varphi \tilde{\omega} \varsigma$ ("light") both in literal and figurative ways. Louw and Nida find that the NT applies the word in three semantic fields, namely, (i) a natural substance (in this semantic field, $\varphi \tilde{\omega} \varsigma$ refers to "the burning vapor surrounding an object on fire"); (ii) an artifact (in this context, the word denotes a tool carried as a light, like a torch); and (iii) a physical event or a state (in this field the word is utilized to express a state that is bright). ${ }^{12}$ Brown also analyzes the word "light" in NT theology and concludes that five words are used to speak about "light," viz., $\lambda \alpha \alpha \mu \pi \omega$ (the function or effect of the light coming from an object), $\varphi \alpha i ́ v \omega$ (to shine, to appear), $\varepsilon \mu \varphi \alpha i \zeta \zeta \omega$ (to reveal or to make

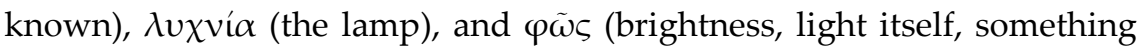
radiating light). ${ }^{13}$ Although the NT authors normally use the word $\varphi \tilde{\omega} \varsigma$ with the literal meaning in mind, in many cases they also use the word to describe something else. One illustration of this is 1 Peter 2.9, in which the author reminds the hearers that God has called them out of darkness into his marvelous light; while this sentence makes use of the word $\phi \omega \hat{~}$ in a literal sense to describe a state that is bright (not dark), the logical structure of this passage also indicates that this image, the state of believers that is bright (not dark), is employed as a metaphor to express the new status and life of God's people, which entails holiness and

\footnotetext{
someone from the Qumran community could be this person.

11 Cf. Andreas J. Köstenberger, A Theology of John's Gospel and Letters, BTNT (Grand Rapids: Zondervan, 2009), 166-167.

12 Johannes P. Louw and Eugene A. Nida, eds., Greek-English Lexicon of the New Testament Based on Semantics Domain, Vol. 1: Introduction and Domains (New York: UBS, 1988), 19-20, 53, 66, 166, 173; Johannes P. Louw and Eugene A. Nida, eds., Greek-English Lexicon of the New Testament Based on Semantics Domain, Vol. 2: Indices (New York: UBS, 1988), 261.

13 C. Brown, "Light, Shine, Lamp," in New International Dictionary of New Testament Theology Vol. 2, ed. C. Brown (Carlisle: Paternoster, 1986), 484.
} 
godliness.

As to the word "darkness," the NT authors employ the word both in a literal and a non-literal way. Louw and Nida identify this term in three semantic fields: (i) a physical event and a state (in the manner of light being scarce between sunset to sunrise); (ii) a mental capacity (in this context, darkness refers to the condition of someone who is lacking understanding); and (iii) a moral quality and related behavior (the word in this field denotes evil behavior or lifestyle). ${ }^{14}$ Likewise, Hahn observes the theological usage of the word and concludes that there are two Greek

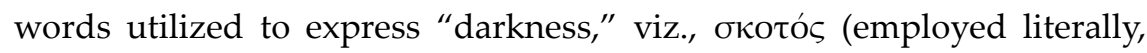
physically and ethically to refer to something evil) and vú darkness). ${ }^{15}$

In 1 John, the author always seems to use the words "light" and "darkness" metaphorically. ${ }^{16}$ He uses the word $\varphi \tilde{\omega} \varsigma$ (six times; 1.5, 7 [twice]; $2.8,9,10$ ) as a quality of brightness, ${ }^{17}$ primarily in a way that highlights God's righteousness. In the same way, he applies the word

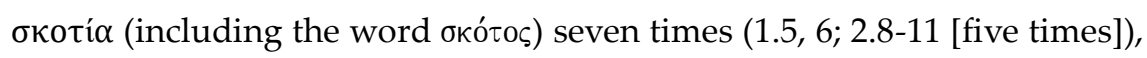
chiefly in a figurative way - to signify the ambience of sinful living.

\section{The Macro-Structure of 1 John}

Reading the syntax structure of 1 John in light of discourse analysis, the present study finds that the letter has 25 units with 98 colas, divided into four sections and two intersections. ${ }^{18}$ The first, Section A (1 John 1.1-

\footnotetext{
14 Louw and Nida, Greek-English Lexicon Vol. 1, 166, 176, 380, 386, 742, 756; Louw and Nida, Greek-English Lexicon Vol. 2, 224.

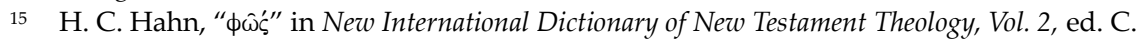
Brown (Carlisle: Paternoster, 1986), 420.

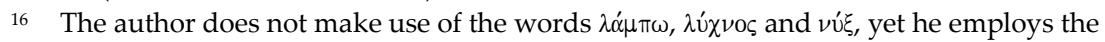

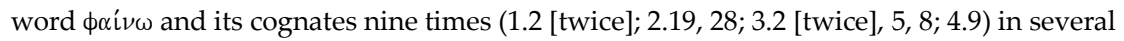
contexts.

17 Even though it is possible that the word $\varphi \tilde{\omega} \varsigma$ in $1 \mathrm{John} 2.8$ refers to the period between sunrise and sunset, the author uses it to illustrate the end of evil works and the beginning of God's kingship in the world and in the lives of God's children.

18 In this essay, "colas" and "colons" refer to the plural form of the word "cola" and "colon." A "colon" represents a simple sentence, and a "cola" refers to a compound sentence. Colas form a unit. Collected units with a unifying thought form a "section." A
} 
$5)$, has one unit, consisting of two colas that form a prologue. Section $B$ (1.6-2.28), which is the first part of the body, consists of 9 units, with 33 colas. An intersection (1 John 2.29-3.1b, containing only one unit, with three colas) connects Section B to the next. Section C (3.1C-5.12), which is the second part of the letter's body, has 11 units, with 54 colas. 1 John 5.13-16 (one unit, with one cola), the second intersection, connects Section $\mathrm{C}$ and Section D (5.17-21; containing two units, with 5 colas), which is the epilogue.

Based on the literary structure of 1 John and its thematic reading, this essay draws the outline of 1 John as follows: 19

1. Section (Prologue) A (1 John 1.1-5): "The Word of Life" in the Christian Faith and Community, and His Message to the Believers (Unit 1$)^{20}$

1.1. Personal Experiences of the Firsthand Witnesses with "the Word of Life"

1.2. "The Word of Life" Brings True Fellowship and Joy

1.3. The Message from the Word of Life, i.e., "God Is Light"

2. Section B (1 John 1.6-2.28): Living in the Light (Units 2-10) ${ }^{21}$

2.1 Those who Live in the Light and the Darkness (Unit 2; 1.6-10)

2.2 Warning about Sin and Request to Obey God (Unit 3; 2.1-3)

2.3 The Importance of Obeying God (Unit 4; 2.4-11)

2.4 Exhortation: Avoiding Sin, Knowing God, and Overcoming Evil (Unit 5; 2.12-14)

2.5 Challenge of Living in the Light: Loving the World (Unit 6; 2.15-17)

2.6 The Example of Those Refusing to Live in the Light: the Antichrist (Unit $7 ; 2.18-20)^{22}$

\footnotetext{
linking unit is named an "intersection."

19 See several outlines of 1 John in Köstenberger, A Theology of John's Gospel and Letters, 172-173.

20 This section begins with a discussion of Jesus as the word of life and ends with the notion that "God is Light," emphasizing that the message comes from Jesus, the word of life.

21 In this unit, the author discusses the practical implication of the notion "God is light."

22 Although the author mentions those who left the community, this does not mean that they still raise a problem in the community. Their case is relevant as an example to illustrate that individuals had failed to live in righteousness and failed to love their fellow believers. Also, it is possible that the author is attempting to anticipate other problems that may occur
} 
2.7 The Explanation of the Example: Sin of the Antichrist (Unit 8; 2.2123)

2.8 Exhortation: Holding the Truth and Living in the Truth (Unit 9; 2.24-25)

2.9 Warning: Be Aware of the Deceiver and Live as God's Children (Unit 10, 2.26-28)

3. Intersection 1 (1 John 2.29-3.1): Who are the Children of God (Units 11$12)^{23}$

3.1 God's Children Live in Righteousness/the Light (Unit 11; 2.29)

3.2 God's Love as a Model for Godly Living (Unit 11; 3.1a, 1b)

3.3 The World does not Know God and God's Children (Unit 12; 3.1c)

4. Section C (1 John 3.2-5.12): Living in Love (Units 13-22)

4.1 The Life of God's Children (Unit 13; 3.2-6)

4.2 Warning: Be Aware of the Deceiver (Unit 14; 3.7a)

4.3 Exhortation: Living in Righteousness (Unit 15; 3.7b-8)

4.4 Warning: Do not Live in Sin (Unit 16; 3.9-10)

4.5 Exhortation: Living in Love (Unit 17; 3.11-13)

4.6 Expanding the Exhortation: Loving Brothers (Unit 18; 3.14-20)

4.7 Self-assessment: Who are We in front of God? (Unit 19; 3.21-24)

4.8 Warning: Be Aware of the Deceiver and Test the Spirit (unit 20;

4.9 Exhortation: Loving God and Loving One Another (unit 21; 4.75.3)

4.10 God's Love and Living in Love (unit 22; 5.4-12)

5. Intersection 2 (1 John 5.13-16): Believing in Jesus (Unit 23)

6. Section (epilogue) D: Sin and Idolatry (Units 24-25)

6.1 Warning: Problem of Sin (Unit 24; 5.17-20)

6.2 Exhortation: Avoiding Idolatry (Unit 25; 5.21)

due to deceivers. The writer seems to interpret the apostasy of those who have left the community as an initial eschatological sign of the antichrist's coming.

23 This intersection emphasizes that the children of God should live in the light (righteousness) and links the previous unit with the next unit, in which the author will stress God's love as a model for believers' love. 


\section{The Concept of "God is Light" in 1 John 1-2}

\section{Light and Darkness in 1.5-7}

To understand the use of the words "light" and "darkness" in 1.5-7, the structure of this passage needs to be analyzed. The following chart illustrates the syntax and constituent (semantic) analyses of 1 John $1.5-7 . .^{24}$

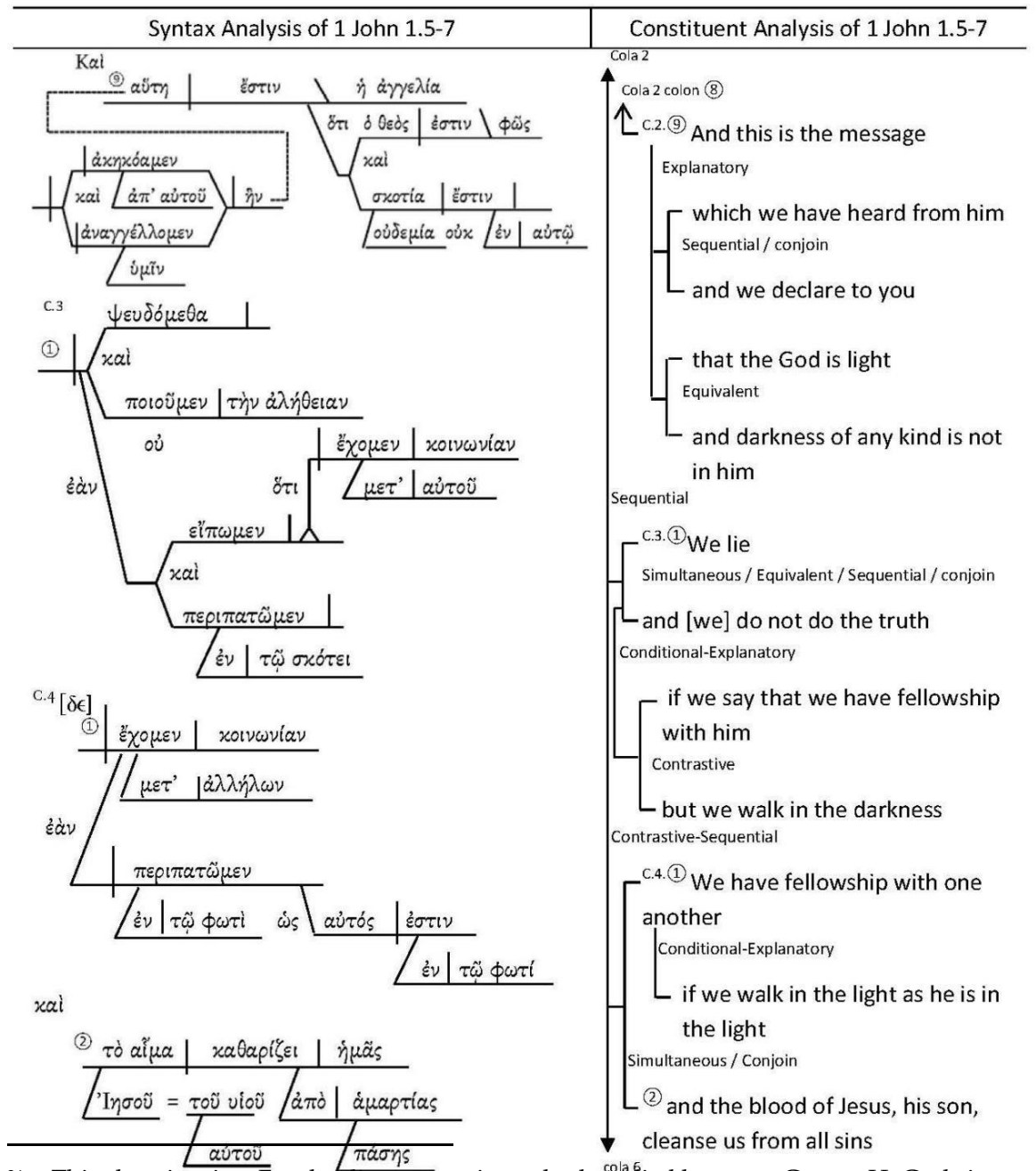

24 This chart is mine. For the diagrammatic method applied here, see George H. Guthrie, "Cohesion Shifts and Stitches in Philippians," in Discourse Analysis and Other Topics in Biblical Greek, ed. S. E. Porter and D. A. Carson, JSNTSS 113 (Sheffield: Sheffield Academic, 1995), 36-59; Thomas R. Schreiner, Interpreting the Pauline Epistles, 2nd.ed. (Grand Rapids: Baker, 2011) 71-113. 
Although the syntax analysis indicates that 1 John 1.5 (C (Cola) 2 colon (9) and 1.6 (C3 colon (1)) are independent units both units are closely related. The notion of God in 1.5 provides the grounds for understanding the author's message in 1.6. The reason that believers cannot have fellowship with God if they walk in darkness (1.6) is due to the nature of God, who is light and in whom is no darkness at all (1.5).

The teaching that "God is light" is essential in the Epistle as a whole and connects the prologue, the body, and the epilogue of 1 John. ${ }^{25}$ This theme becomes the central idea of something called "the message" in 1 John 1.5. The syntax structure of this passage displays that the author's primary purpose is to remind his hearers of something

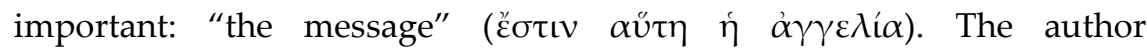
emphasizes that "the message" comes from an influential person ( $\hat{\eta} v$

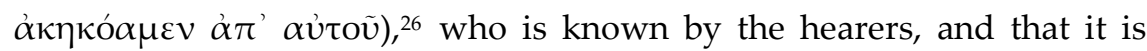
related to the "God is light" teaching, which is vital in Christian faith and proclamation. When the author says that the "God is light" idea comes from the one who is trusted, he validates not only the authenticity of this person's teaching but also the significance of the message.

The message that "God is light" is significant in that it becomes the central point of the teaching and preaching of the authoritative people called "we" in 1 John. Scholars have proposed several interpretations to explain the "we" notion in the Epistle. Brown, for instance, argues that the "we" in 1 John, including 1.5, points to the Johannine School, which is responsible for maintaining the Johannine traditions. ${ }^{27}$ In contrast, other scholars, such as Lalleman, Bauckham, Lieu, and Van Houwelingen,

\footnotetext{
25 Cf. Robert W. Yarbrough, 1-3 John, BECNT (Grand Rapids: Baker, 2008), 21.

26 The pronoun aùtov is likely to refer to Jesus. Although the phrase "God is light" does not occur elsewhere in the Johannine literature, the concept of living in the light recurs in Jesus' teaching preserved in the Johannine tradition (see, e.g., John 12.6). The message that believers should live in the light is rooted in Jesus' teaching, and likewise, the concept of "God is light," the grounds for the message of living in the light, must also anchor in the Jesus tradition; cf. Marshall, The Epistles of John, 108.

27 See Marshall, The Epistles of John, 94-96.
} 
propose that the "we" in 1 John refers to witnesses of Jesus. ${ }^{28}$ Bauckham is correct in claiming that the pronoun "we" in the letters of John can be used as an exclusive "we" (e.g., 1 John 1.1-3), an inclusive "we" (e.g., 1 John 1.6-7), and a royal "we" (e.g., 3 John 9). ${ }^{29}$ While in 1.6-7 the "we" refers to the author and the addressees, in 1.5 the "we" probably is used as the exclusive "we," alluding to those who had a personal experience with the incarnated Jesus, like the twelve apostles, Matthias (who replaced Judas Iscariot), and Barsabbas (cf. Acts 1.15-23). Since the "we" seems to refer to witnesses who have directly seen Jesus, it is hard to believe that the notion points to the Johannine School, which is the community of John's sectarian disciples who preserve Johannine traditions.

In 1 John 1.5-7, the author reveals his concern for believers regarding their real life issue, namely, the problem of sin. The syntax and constituent analyses of the passage show that the author intends to help his readers recognize that believers should not walk in darkness. ${ }^{30}$ The contrasting form used by the author to relate 1.5 and 1.6, and also within 1.6-7, indicates a semantic relation between these units; ${ }^{31}$ this also suggests that the author is attempting to rectify something wrong in his readers' understanding. Using contrasting expressions in these units, the

28 See Pieter J. Lalleman, 1, 2 en 3 Johannes: Brieven van een Kroongetuige, CNT (Kampen: Kok, 2005), 128-129; Richard Bauckham, Jesus and the Eyewitnesses: The Gospels as Eyewitnesses Testimony (Grand Rapids: Eerdmans, 2006), 358-411; Judith Lieu, I, II, III John: A Commentary, NTL (Louisville: Westminster, 2008), 40-41; P. H. R. van Houwelingen, "John and Others: To Whom Does 'We' in the Fourth Gospel's Prologue and Epilogue Refer?" Fides Reformata XIX.2 (2014), 95-115.

29 Cf. Bauckham, Jesus and the Eyewitnesses, 371, 372, 374, 375.

30 There are four colas in 1 John 1.5-7 (cola 2 colon (9), cola 3 colon (1), cola 4 colon (1), and cola 4 colon (2)). The constituent analysis finds that these clauses are semantically connected and form two interrelated parts; similarly, while there is no conjunction that links cola 1.5 and cola 1.6-7, the semantic reference to the word "darkness" bounds these units.

31 NA 28 notes that some manuscripts (a, A, B, C, P, 5, 33, 81, 307, 436, 442, 642, 1175, 1448, $1611,1735,1852,2344,2492, \mathrm{Byz}, \mathrm{sy} \mathrm{co}, \mathrm{Cl})$ use the conjunction $\delta \varepsilon \dot{~ i n ~ t h e ~ b e g i n n i n g ~ o f ~ c o l a ~} 4$ colon (1) but other manuscripts (Y, 1243, 1739, 1881, 1, $z^{*}$, bo mss, Cry) do not use the word. Although some old manuscripts (such as, codex Sinaiticus and codex Alexandrinus) support the use of $\delta \dot{\varepsilon}$, the internal evidence indicates that the word is probably a later addition. 
author appears to be, for the sake of his audience's edification, highlighting the substantial difference between light and darkness (i.e., living in God and living in sin), using the "God is light" notion to emphasize how impossible it is for a child of God to live in sin, remaining in the darkness.

In 1 John 1.5-7, the author develops a teaching about God that appears to be in response to a particular situation, including its various ethical implications. The author explicitly states the vital message for his

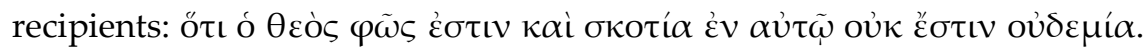
These sentences contain two interrelated subjects. First, they say that "God is light." The word "light" in this sentence is a metaphor, and in this colon it functions as a predicate nominative, which means that the word "light" describes something about God-in particular, his identity and activity. ${ }^{32}$ While some scholars argue that the metaphor signifies God's revelatory action, ${ }^{33}$ the word "light" could also refer to God's holiness. ${ }^{34}$ Since it is not possible to find more evidence in this short colon that would help us to understand the meaning of this metaphor, the investigation should be expanded to the next clause, namely, the

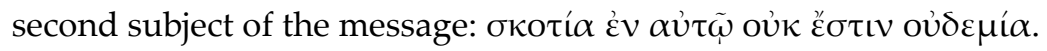

To underscore this declaration, the author writes this second sentence, which also helps his hearers to understand the type of light he is describing. Basically, the author is clear enough when he says that God is light because it implies that darkness is not in him, but he forms a contrastive sentence to display that he is not merely speaking about God as the creator of day and night; ${ }^{35}$ instead, he utilizes the word "light" to emphasize that God is holy and true, who cannot tolerate any sin.

This conclusion is supported by the fact that 1 John never applies the concept of darkness to describe a person's intellectual and mental

\footnotetext{
32 See Brown, The Epistles of John, 194-195.

33 See, e.g., Painter, 1, 2, and 3 John, 138-139.

34 Cf. Marshall, The Epistles of John, 109.

35 It means that the term "God is light" does not refer to God as the creator of any lightgiving artifacts (the sun and the moon, for example).
} 
capacity (like that of an individual who lacks understanding), but exclusively employs it to describe an immoral orientation to life (specifically, a lifestyle of habitual sin). For example, in 1.6-7, the author makes reference to those who walk in the darkness ( $\dot{\varepsilon} v \tau \tilde{\omega}$ okó $\tau \varepsilon \iota$ $\pi \varepsilon \varrho \iota \tau \alpha \tau \tilde{\omega} \mu \varepsilon v)$. At the same time, the author also makes use of the metaphor in 2.8-11, and, similar to the OT (especially the book of Proverbs; see, e.g., 2.13, 4.19, 8.20), he uses the term (darkness) to describe those who have sinful lifestyles (cf. 1 John 2.8-11). As the word "darkness" used in contrast to the word "light" is related to sinful living, the metaphor of light in 1 John refers to the opposite, that is, the holy and righteous way of life. Similarly, the proclamation that God is light seems to imply his holiness as well as his righteousness. Compared to 1 John 1.5-6, in which the author exhorts the hearers to live in the light due to God being light, in 2.29 (see also 3.7-8) the author explicitly spells out that God is righteous and that, consequently, those who live in him (those who walk in the light) should live in righteousness. In light of this analysis, it seems reasonable to define the word "light" in cola 1.5 as "God's holiness and righteousness"; this principle may also include justice as the main part of his holy and righteous character.

Why does the author feel the need to say this? The constituent analysis may help to answer this question. It suggests that 1.5 functions as the grounds for correcting some behavior. In addition, 1.6-7 reveals that some individuals in the community might have sinful lifestyles (see also 2.1). Even though the author makes use of the subjunctive mood when he says "we walk in the darkness," 36 this statement could express a real issue faced by the congregation. ${ }^{37}$ Also, some issues in the church

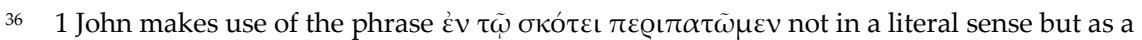
theological term; it expresses the evil realm in which one lives (see Harris 2012, 133-136).

37 The teaching about love is a recurring theme in 1 John (in particular, 2.9-11, 3-12-17, and 4.20-21), which makes it a major theme in this document that may indicate a real situation in the church, a circumstance the epistle addresses directly. The allusion to Cain, who killed his brother (3.10-12), is used as an example of those who live in darkness; it also implies that there is a social and relational problem in the congregation. Additionally, the emphasis placed upon the "fellowship" among God's children supports the conclusion that there was a
} 
which are repeatedly mentioned in this letter (like loving the brothers and sisters), suggest that fellowship might have been an issue among the addressees. At the same time, the author also employs contrasting statements in 1.6-7; to be specific, in this passage he distinguishes

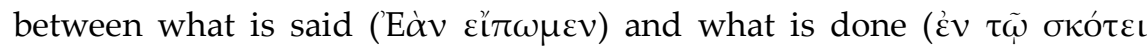
$\pi \varepsilon \varrho เ \pi \alpha \tau \tilde{\omega} \mu \varepsilon v) .{ }^{38}$ Further, the author deliberately draws on the word oủ $\delta \varepsilon^{\prime} \alpha$ in 1.5 to underline his point that God and sin (darkness) cannot coexist. This emphasis seems to imply that some individuals in the community struggle with consistency, their actions failing to align with their confessions. If this is the problem, 1 John appears to be using the "God is light" teaching to stress God's intolerance of sin (cf. 1 John 5.16). In this context, 1 John uses the statement that "God is light" as the ground for requiring a consistent lifestyle by which believers imitate God, who will not overlook lifestyles of habitual sin. Hence, the lifestyle of practicing sin clearly is a problem for those who want to live in the light.

\section{Light and Darkness in 1 John 1.1-5}

Since 1 John 1.5 is syntactically related to $1.1-4$, it is important to discuss the relation between the notion of "God is light" in 1.5 and the notion of "the word of life" in 1.1-4. The syntactic and constituent analyses of 1 John 1.1-5 can be seen in the following charts.

relational problem among them.

38 Cf. Porter, Idioms, 263. He argues that the continued opposition of present and aorist subjunctive, i.e., opposition between "what is said" and "what is done" in 1 John 1.6-10, affirms the second element. 


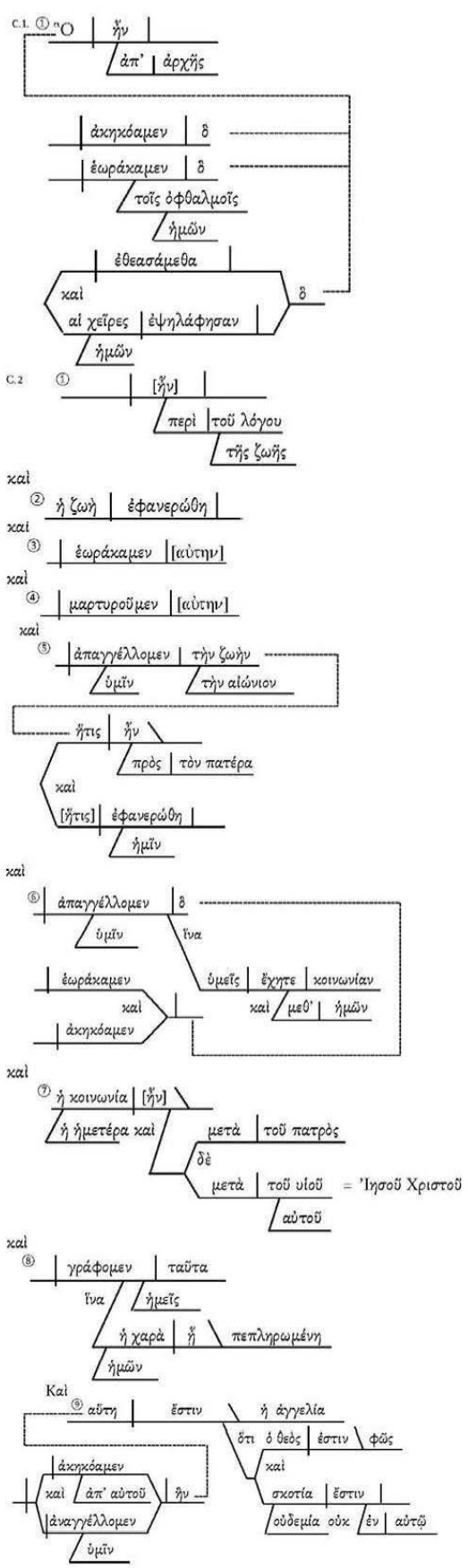

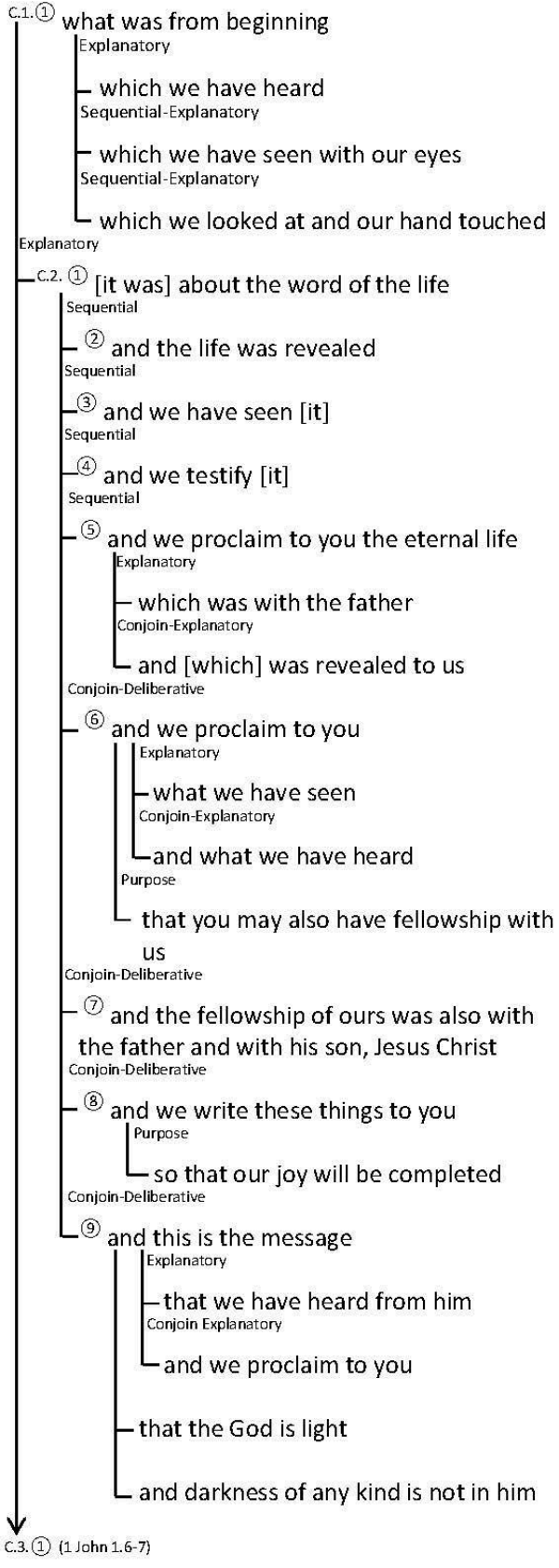


The text structure above displays that "the word of life" emerges

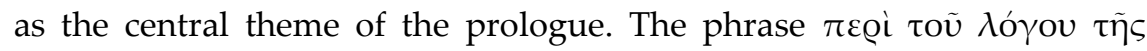
$\zeta \omega \tilde{\eta} \varsigma$ is somewhat enigmatic. ${ }^{39}$ It does not seem to correlate well with the

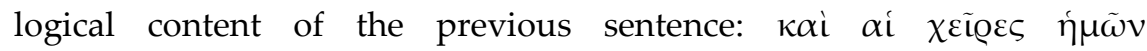
$\dot{\varepsilon} \psi \eta \lambda \alpha \dot{\alpha} \varphi \sigma \alpha v .{ }^{40}$ On the other hand, the idea of "the life" applied in the phrase is developed in the next cola (1 John 1.2-4). The conjunction $\kappa \alpha i$ used at the beginning of 1.2 indicates that this sentence is still linked to the previous sentence; nevertheless, if we connect 1.2 directly to the main

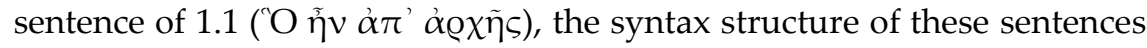
are also not connected well. However, the logical structure of this phrase can be fitted with the previous and the next sentence if the same verb

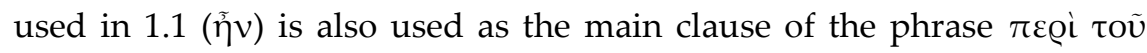

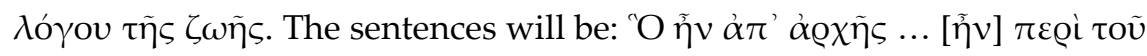

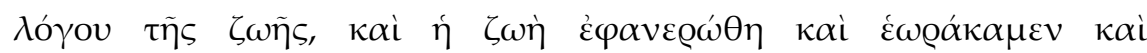

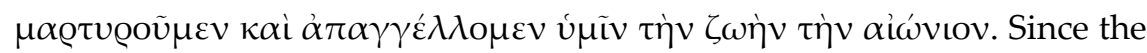
author of 1 John sometimes omits a verb between coordinate sentences when they use the same verb, ${ }^{41}$ it is possible that he does the same in $1.1 \mathrm{~b}$, omitting verb $\tilde{v} v$ to avoid repetition. If this construction is correct, the author means by 'something which was from the beginning,' that which has become the core of the believers' faith since the beginning, which is

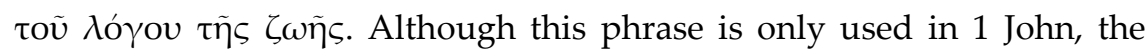
concept of "the word" that brings "life" is more developed in the Gospel of John (John 1.1-5), which has the same idiolect as 1 John, and therefore, it is reasonable to argue that the phrase points to Jesus. This Jesus, the word of the life, brings eternal life (1.2), becomes the center of believers' fellowship (1.3), and is the basis for the author's joy and hope (1.4).

\footnotetext{
39 The genitive clause probably should be seen as a phrasal signal specifying the author's intent to narrow the conversation to a subject that is more important.

40 Cf. Lieu, I, II, III John, 41.

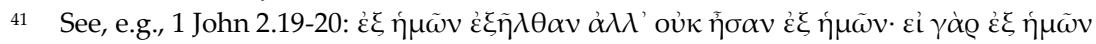

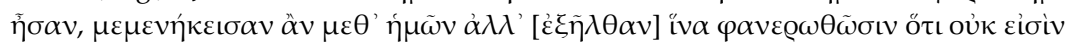

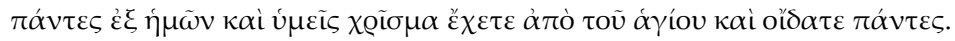


What is more, the structure of 1.1-3 syntactically appears to form a concentric structure, placing cola 1.2 as its core. The author may deliberately have created this pattern to help his readers understand that the essence of the Christian proclamation, which is not explicitly mentioned in 1.1 and 1.3, is related to Jesus, "the word of life." The constituent analysis also confirms that the special focus of these units lies in 1.2. Cola 1 reveals that the author has proclaimed something that is fundamental to the Christian belief, and cola 1.2 further explains a central doctrine within this Christian proclamation; finally, in cola 1.2 he helps his readers to recognize that the central point of this unit is "the word of life," i.e., Jesus the Son of God.

Why does the author need to underline this teaching? It is possible to understand the importance of this theme in light of the Christological issue that occurs among the addressees (cf. 1 John 4.2-3). This issue is related to those who have left the congregation (see 2.18-19). Unfortunately, the author does not speak much about them; as a result, information must be inferred through implication. ${ }^{42}$ It is very likely that they rejected the teaching about Jesus' incarnation (4.2-3). Besides, Lalleman has shown that the way in which the author of 1 John expresses the experience of "seeing" and "touching" (1 John 1.1) implies what is rejected by that group: the humanity of Jesus. ${ }^{43}$ Moreover, some scholars also find indications that the group probably rejected not only Jesus' humanity, but also his death as the atonement for humanity's sins (cf. De Boer 1991, 326-346). One such indication is that in 2.1-2 the author emphasizes that Jesus is the righteous one who has become an atoning sacrifice for humanity's sin; apparently, this needs to be stressed because

\footnotetext{
42 For a detailed discussion of the opponents in 1 John, see Streett, They Went out, 5-111.

43 Pieter J. Lalleman, "The Adversaries Envisaged in the Johannine Epistles," NTT 53 (1999): 18-20. Lalleman, having analyzed the Apocryphal Acts of John and compared it to 1 John, concludes that there is a similarity between the teaching of those who are combated in 1 John and the Christological teaching of the Apocryphal Acts of John, the opponents of 1 John and the author of the Apocryphal Acts of John rejecting Jesus' humanity. Lalleman also believes that this teaching occurs because of a spiritual reading of the Gospel of John that leads the readers of the Apocryphal Acts of John to hold to Christomonism.
} 
some may doubt or reject it.

The author begins his writing with a Christological statement about Jesus because this is probably the most relevant issue affecting the addressees. Although the adversaries had left the community, the issue probably is not over. Another problem may arise. Some people in the community may live a sinful life. The fact that the author brings up the Christological issue and ethical issues in the prologue indicates that the two are related.

To tackle this issue, 1 John maintains that one who truly believes in Jesus should wholeheartedly accept him as the Son of God who has come as a human being and died for humankind's sin, and should live in the Light. This basic belief determines whether an individual is truly a part of God's people (cf. 1 John 2.19). This confession about Christ and the commitment to live in the truth also reveal if one has eternal life; although they may live among believers, those who reject Christ's human nature-and, by consequence, his atoning sacrifice for humanity's iniquity - cannot enjoy true life.

Similarly, when the author states that the purpose of this writing is

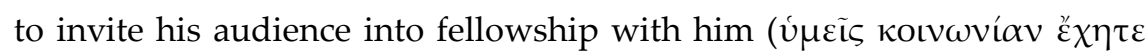
$\left.\mu \varepsilon \theta^{\prime} \eta \mu \tilde{\omega} v\right)$, he desires the hearers to make a firm choice not to follow those who had left the church; to steadfastly hold the apostolic teaching regarding Christ, the basis for developing true and genuine fellowship and the key to having eternal life; and to know that true fellowship leads believers to live in truth.

Further, the writer shows his expectation that he and his hearers will have a joyful fellowship. To express this expectation, he deliberately uses the expressions $\tilde{\eta} \pi \varepsilon \pi \lambda \eta \varrho \omega \mu \varepsilon \dot{v} \eta$ ("be completed") and $\eta \chi \chi \alpha \varrho \dot{\alpha}$ (the joy), the latter is a hapax in 1 John. These words express a state of gladness that will manifest itself in genuine fellowship between the author and the hearers. Yarbrough maintains that the author of 1 John sees the true Christian fellowship consists of a threefold relationship namely: (i) the fellowship between the hearers and God the Father and 
Christ; (ii) the fellowship between the hearers and the author (those who are called "we"); and (iii) the fellowship amongst the believers in the community. ${ }^{4}$

The fact that the author joins together, respectively, the importance of true belief in Jesus, the sound teaching about Jesus, the concepts of eternal life and true fellowship, and the importance of living in accordance with God's character (especially his holiness and righteousness), signals that he wants his hearers to be aware that this true fellowship with God and their fellow believers will not happen if the congregation tolerates erroneous teachings about Christ and the sinful lifestyles of those who do not truly believe in Christ. The church should understand that the eternal life received by believers leads them to live in the light.

\section{"Light and Darkness" in 1 John 1.8-9}

The problem faced by the community may also be reflected in the hypothetical statement in 1 John 1.8-10. In this unit, the author mentions individuals who claim that they do not have sin ('E $\alpha v$ عĭ $\pi \omega \mu \varepsilon v$ ö $\tau$ เ

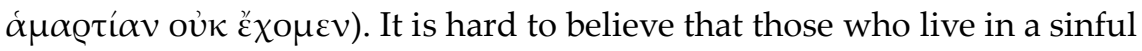
manner (cf. 1 John 1.6-7) are the same people who say that they are free from the sinful nature. ${ }^{45}$ Some scholars argue that there are different opponents envisaged in 1 John, including those who believe in

\footnotetext{
44 Cf. Yarbrough, 1-3 John, 53.

45 Lieu $(2008,57)$ argues that the author deals with the logical consequence of his teaching about true fellowship in God and Christ; he may think that his hearers have concluded that this fellowship makes them perfect (sinless) or sets them free to do anything. Equally, Thielman $(2005,546)$ thinks that those who live in $\sin$ in 1 John are individuals who believe in Jesus but argue that their fellowship in him enables them to step outside the realm of sin, such that they are like Christ who is without sin, or who see sin as an irrelevant subject. Marshall (The Epistles of John, 112-113) argues that the claim of those who say that they have no sin indicates that the opponents have a different view of sin from the author; in other words, whereas the author clearly states that what they do is sin, they deny it. Although it is possible that the author of 1 John seems to anticipate an objection that may occur in response to his previous teaching, this issue may still relate to the Christological issue (on the human nature of Jesus), something that has become the main controversy among the addressees of 1 John.
} 
perfectionism. ${ }^{46}$ However, because 1 John $1.8-10$ is still related to the previous units, ${ }^{47}$ we may conclude that the ones who claim to be free of sin, essentially, are the same people who have sinful lives, those who walk in the darkness, and also those who reject Christ's incarnation and his atoning sacrifice. Given that the author's opponents reject the reality of human sinfulness, they see no need to believe in Christ as the atoning sacrifice for all of humanity's sins. This group possibly sees sin as a part of human nature from the beginning; in fact, they may believe that God also has a similar nature. Therefore, while the author of 1 John emphatically says that evil deeds stem from sin, they probably recognize them only as natural weaknesses that are intrinsic to human nature. Therefore, the author emphasizes that God is light and that there is no darkness (sin) in him, so that those who claim to be his people (children of God) will not stay in $\sin$ (see, e.g., 1 John 2.29, 3. 4-6).

Thus, the statement "God is light" was possibly written to lead those who believe in Christ to embrace the sound doctrine about Christ and to maintain a consistent life in accordance with God's will. This precept is essential because the hearers face not only the theological issues regarding the human nature of Jesus and his death but also the ethical implication of this belief, which probably has affected other individuals in the community. The author attempts to pastor the group that has been influenced by those who had left the congregation.

\section{Light and Darkness in 1 John 2.9-11}

In the first chapter of 1 John, the author discusses the principle of "light and darkness" in its relation to the teaching of God (cf. 1 John 1.5). In chapter 2 he addresses it again but links it to the notion of Christ (cf. 1 John 2.1-2). The metaphor of light and darkness is found in 1 John 2.8-11. The following chart describes the syntactic relation and the constituent

\footnotetext{
46 Cf. Stephen Smalley, 1, 2, 3 John, WBC (Nashville: Thomas Nelson, 1984); J. Bogart, Orthodox and Heretical Perfectionism in the Johannine Community as Evident in the First Epistles of John, SBLDS 33 (Missoula: Scholars, 1977).

${ }_{47}$ The word $\alpha \mu \alpha \varrho \tau i ́ \alpha$ in 1 John 1.7 and 1.8 semantically links cola 1.5-7 and cola 1.8-10.
} 
structure of the units.

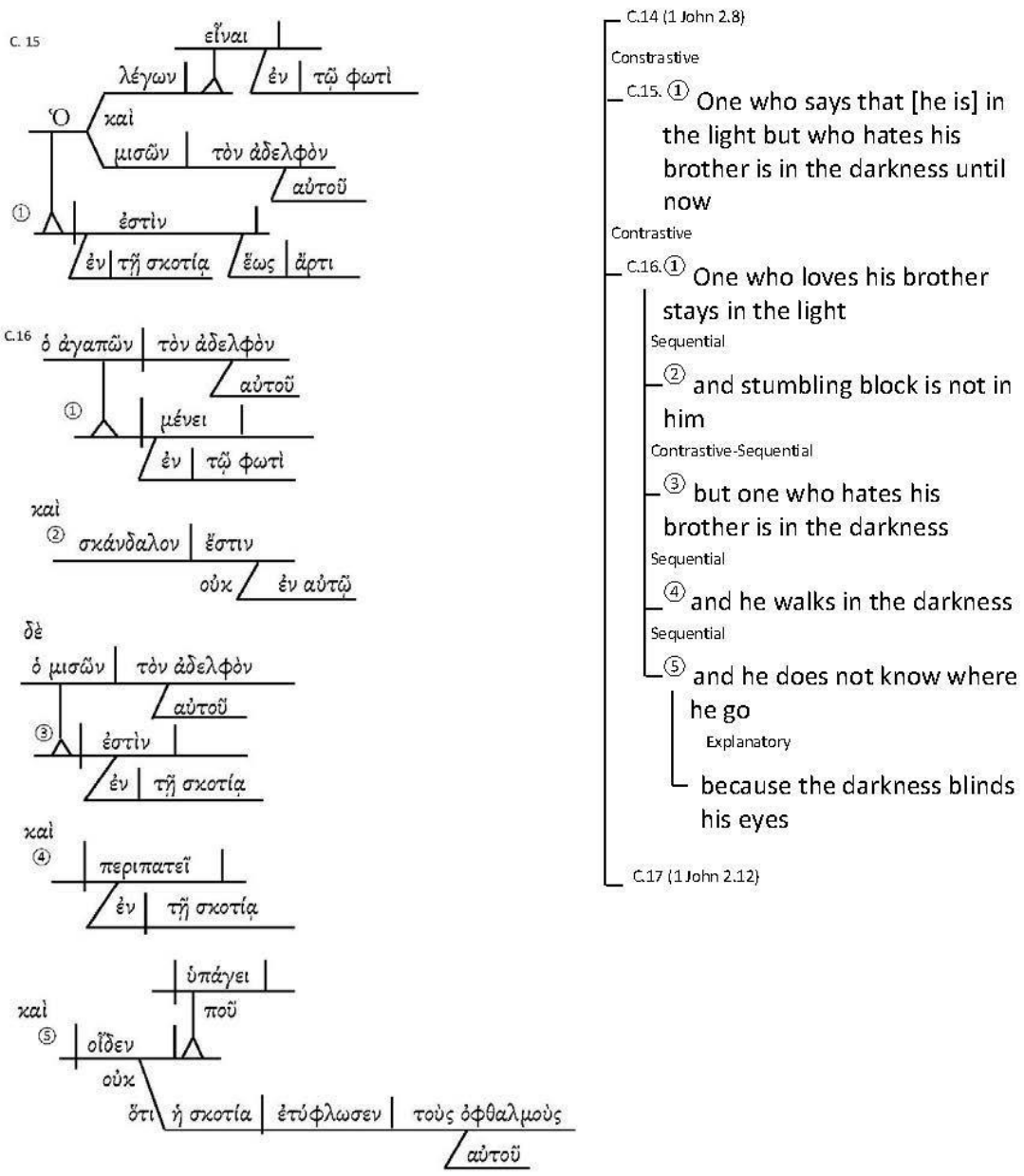

The second chapter of 1 John forms a bridge between the first chapter and the other parts of this letter. While the first part of 1 John develops the idea of God being light and its ethical implication, that is, living in the light, the second part speaks about the inextricable relation between living in light and living in love. In this second chapter, the author underscores the significance of living in holiness as a consequence

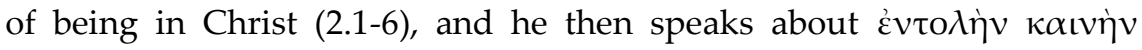
("new instruction") that should apply to believers' lives and in their community (see 2.7-9). 
What is the meaning of this term? The author also uses the word $\dot{\varepsilon} v \tau o \lambda \eta े v$ in 2.3-4, where it presumably refers to God's instructions. Although in 1 John 2.3-4 and 7-8 the author does not clearly state what he means by this word, in other parts of this letter he apparently uses the word in reference to God's instructions (cf. 3.21-24; 5.2-3). Also, the word $\pi \alpha \dot{\alpha} \lambda \mathrm{\iota}$ in 2.8 displays that this unit is not an inverse of 2.7; it functions as an additional explanation of the previous unit. The author mentions that

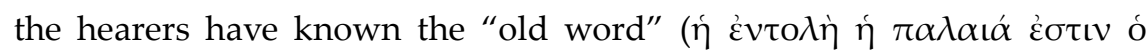

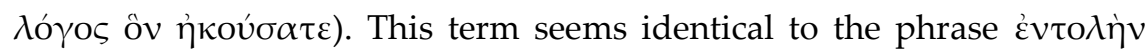

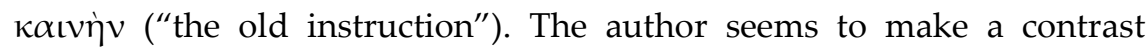
between this "old instruction" and the new one, yet he only wants to remind his hearers that this old tradition has something new. ${ }^{48}$ Despite the fact that, in cola 2.8, he mentions that this new instruction is related to the injunction to live in the light, he makes use of the word $\dot{\varepsilon} v \tau o \lambda \dot{\eta} v$ to point to the love instruction of Jesus (cf. 1 John $3.23 ; 4.21$; John 13.13). In this case, the phrase "old instruction" may refer to the OT teaching about love (in particular, Leviticus 19. 18), and the new instruction may point to the new application of this OT instruction by Jesus. This statement indicates that the author may be drawing from the OT and interpreting it in light of the truth of Christ. Lieu is probably correct when she argues that the old word specifically refers to God's law in Leviticus 19, which the opponents fail to apply; the difference between the old application and the new one is based upon one's motive and grounds for obeying God; true obedience will occur in the life of those who receive the true life in Christ. ${ }^{49}$ Those who reject the incarnated Jesus, as Israel rejected God in the OT, will not be able to obey and sincerely love God and his people, since it is only the sacrifice of Jesus the son of God that enables a person to accept true forgiveness, true knowledge of God, and true spiritual conquest over darkness. ${ }^{50}$

\footnotetext{
48 Cf. Yarbrough, 1-3 John, 99-100.

49 Cf. Lieu, I, II, III John, 76.

50 Ibid.
} 
The author writes this message because the work of Christ entails a new interpretation of the law that has become obsolete now. The phrase of

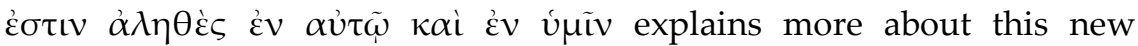
understanding. While the phrase "true in him" probably refers to what Jesus has done (that is, his incarnation and atoning death), the author underlines that Jesus' work should lead to real change in the lives of those who follow him. To put it differently, he maintains that true fellowship in Christian community, when people sincerely love one another, reveals and confirms what is true.

To show this, the author clarifies what he means by "what is true" (see colon 2 and 3). He says that the truth is related to the end of the

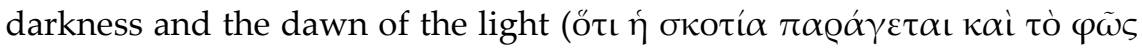

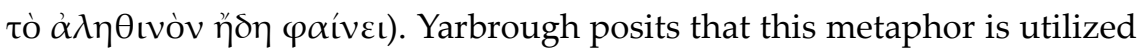
to expound the coming of Christ, which will make an end the realm and rule of evil; the structure of 1 John 2.1-8 supports this proposal; in 2.1-2, the author proclaims the righteous death of Christ and his triumph over evil once and for all. ${ }^{51}$ Plausibly, the author applies the metaphor of the sun's rising as an analogy of Christ's coming into the world. In other

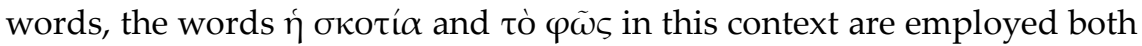
literally and figuratively to underline the changing realities in the human realm as a result of the birth of Christ. The author also uses Christ's work as a ground for encouraging the congregation not to live in a sinful way but to live in love with one another; Christ's works should eradicate habitual sin in believers' lives and empower them to love one another. At the same time, the author seems to teach them to love in a new way. Although they are told to love their fellow Christians as their brothers and sisters, in Christ they also have to learn to love all people (including those who still live in the darkness [in the world]), because Jesus loves them and his death is also for them (cf. 1 John 2.2). Interestingly, the author continues to write about this theme in 1 John 3. In fact, he makes use of the story of Cain (3.12) who killed his brother to exemplify the evil

51 Cf. Yarbrough, 1-3 John, 102. 
deeds of those who stay in darkness.

\section{Conclusion}

The concept of God is clearly vital in 1 John, and the author applies the metaphor of light to illustrate God's righteous and holy character; this theme clearly influences the flow of argument in 1 John 1-2. In the first chapter, the author emphasizes how God's children must live in the light as God himself is light. In chapter 2, while he still stresses the importance of living in the light, he focuses more on driving home the point that Christ came in the flesh and died to atone for the sins of the entire world (2.2), two facts that should inspire loving self-sacrifice within a true Christian community.

The method of discourse analysis, applied to 1 John, reveals that the author develops the idea of God being light in order to teach the hearers to live in accordance with their belief. Also, this way of reading helps interpreters to understand that the main issue in this letter is not only the teaching about the humanity of Christ but also the ethical implications of its heretical antithesis. The two themes of God being light and of living in light, both of which are fundamental in 1 John 1-2, are clearly expounded by the author to elucidate what it means to have eternal life, which is given to those who believe in Jesus' work (i.e. his incarnation, death, and resurrection). 1 John helps its readers to discover that having eternal life means living in righteousness, holiness, and love. 